\title{
Two Guanylylcyclases Regulate the Muscarinic Activation of Airway Smooth Muscle
}

\author{
Marcelo J. Alfonzo, Fabiola Placeres-Uray, Walid Hassan-Soto, \\ Adolfo Borges, Ramona González de Alfonzo and Itala Lippo de Becemberg
}

Additional information is available at the end of the chapter

http://dx.doi.org/10.5772/48684

\section{Introduction}

Muscarinic activation of Airway smooth muscle (ASM) is of major importance to the physiological and patho-physiological actions of acetylcholine, which induces bronchoconstriction, airway smooth muscle thickening, and the modulation of cytokine and chemokine production by these cells as described in [1]. The parasympathetic nervous system is the dominant neuronal pathway in the control of airway smooth muscle tone. Stimulation of cholinergic nerves causes bronchoconstriction, and mucus secretion as in [2]. The human airways are innervated via efferent and afferent autonomic nerves, which regulate many aspects of airway function. It has been suggested that neural control of the airways may be abnormal in asthmatic patients, and that neurogenic mechanisms may contribute to the pathogenesis and pathophysiology of asthma. Although abnormalities of the cholinergic innervation have been suggested in asthma, thus far the evidence for cholinergic dysfunction in asthmatic subjects is not convincing as mentioned in references [1,2].

Acetylcholine (Ach) is the predominant parasympathetic neurotransmitter, acting as an autocrine or paracrine hormone in the airways and its role in the regulation of bronchomotor tone and mucus secretion from airway submucosal glands in the respiratory tract is well established as described in [2]. More recent findings suggest that acetylcholine regulates additional functions in the respiratory tract, may promoting airway inflammation and remodelling, including airway smooth muscle thickening in inflammatory lung diseases as reported in references [3-5]. Another source of ACh is the non-neuronal cells and tissues, particularly inflammatory cells and the airway epithelium as described in references [6-8].

Collectively, these findings indicate that acetylcholine, derived from the vagal nerve and from non-neuronal origins such as the airway epithelium, may induce cell responses associated with airway wall remodelling and trigger proinflammatory Cytokines as IL-6 and 
IL-8 release in [9] by structural cells of the airways, including the airway smooth muscle itself. In addition, muscarinic receptors regulate proliferative and proinflammatory functions of the airway smooth muscle as mentioned in references $[9,10]$.

Acetylcholine acting on muscarinic receptors (mAChRs) anchored at the airway smooth muscle sarcolemma are involved in the generation of a number of signal transducing cascades allowing the activation of the smooth muscle machinery as described in [11]. Airway smooth muscle muscarinic activation is mediated through mAChRs, which are members of the so called G protein-coupled receptors (GPCR) family, which are cell surface receptors, that activate intracellular responses by coupling $G$ proteins as described in [12] to specific effectors in [13]. Molecular cloning studies have revealed the existence of five mammalian subtypes of muscarinic receptors (m1-m5) as described in [14]. In trachea, smooth muscle expresses mRNAs coding for both $\mathrm{m} 2$ and $\mathrm{m} 3$ receptors as reported in [15]. Airways smooth muscarinic receptors have been identified as a mixed population of $\mathrm{M}_{2}$ and M3 subtypes roughly in a 4:1 ratio using pharmacological ligand binding studies in $[16,17]$ being the $\mathrm{M}_{2}$ subtype, the most abundant muscarinic receptor in tracheal plasma membranes as reported in references $[16,18,19]$. In addition, a muscarinic antagonist heterogeneity associated with the $\mathrm{M}_{3} \mathrm{AchR}$ subtype present in plasma membrane fractions from tracheal smooth muscle has been described in [20].

It has been claimed that $\mathrm{M}_{3} \mathrm{AChR}$ represents a primary target of acetylcholine in the airways, involved in the regulation of bronchoconstriction as stated in references [17,18,21,22]. Classically, M3AChRs in ASM are coupled to phospholipase C (PLC)/protein kinase C (PKC) pathway via pertussis toxin (PTX)-insensitive $\mathrm{G}$ proteins of the $\mathrm{Gq} / 11$ family. The contractile response evoked by $\mathrm{M}_{3} \mathrm{AChRs}$ stimulation is attributed to the formation of inositol trisphosphate (IP3), the subsequent release of $\mathrm{Ca}^{2+}$ from intracellular stores, the additional influx of extracellular calcium, and the $\mathrm{Ca}^{2+}$-sensitizing effect of PKC as mentioned in $[21,23,24]$.

On the other hand, the stimulation of $\mathrm{M}_{2}$ muscarinic receptors ( $\left.\mathrm{M}_{2} \mathrm{AChRs}\right)$ in ASM inhibits adenylyl cyclase via activation of PTX-sensitive G proteins of the Gi/o family in $[25,26]$ and therefore $\mathrm{M}_{2} \mathrm{AChRs}$ are thought to counteract relaxation as reported in [27]. Experimental evidence has been provided that $\mathrm{M}_{2} \mathrm{AChRs}$ participate directly in ASM contraction but the molecular mechanisms by which the $\mathrm{M}_{2} \mathrm{AChRs}$ in ASM induce contraction is, still unknown.

Recently, it has been shown that $\mathrm{M}_{2} \mathrm{AChRs}$ stimulate Gi/o proteins to released $\beta \gamma$ dimer, which inhibit the Large Conductance $\mathrm{Ca}^{2+}$-activated $\mathrm{K}^{+}$Channel Activity (BK channels) as described in [28]. The inhibition of BK channel activity favors contraction of ASM and these BK channels are opposed to the $\mathrm{M}_{2} \mathrm{AChR}$-mediated depolarization and activation of calcium channels by restricting excitation-contraction coupling to more negative voltage ranges as mentioned in [29].

In addition, the influence of $\mathrm{M}_{2} \mathrm{AChRs}$ to modulate the relaxant effects of atrial natriuretic peptide (ANP) has been reported. Thus, the stimulation of $\mathrm{M}_{2} \mathrm{AChRs}$ suppresses ANPinduced activation of particulate guanylyl cyclase via a PTX-sensitive G protein as reported in [30]. 
More recently, we showed that muscarinic agonists, via $\mathrm{M}_{2} \mathrm{AChR}$ induced a massive and selective $\alpha 1 \beta 1-N O s G C$ migration from cytoplasm to plasma membranes in a dosedependent manner. Such migration was blocked by PTX, suggesting the involvement of Go/Gi proteins in [31].

Some of the signal cascades activated by mAChRs at TSM are linked to the generation of second messengers such as cyclic nucleotides: cAMP and cGMP as described in reference [32]. In this review, we address the cGMP generation as a product of the muscarinic activation of ASM. It is well known that in mammalian cells, cGMP is produced by the action of two distinctive guanylyl cyclases, named the NO-sensitive soluble guanylylcyclases (NO-sGC) as reported in [33] and the single membrane-spanning guanylyl cyclases as published in references [33-35].

\section{Body: Cyclic GMP signals during muscarinic activation}

The muscarinic activation of tracheal smooth muscle (TSM) fragments associated with smooth muscle contraction, involves the generation of two cGMP signals, at 20-s and 60-s as described in reference [36] and a kinetic behavior is shown in Figure 1.

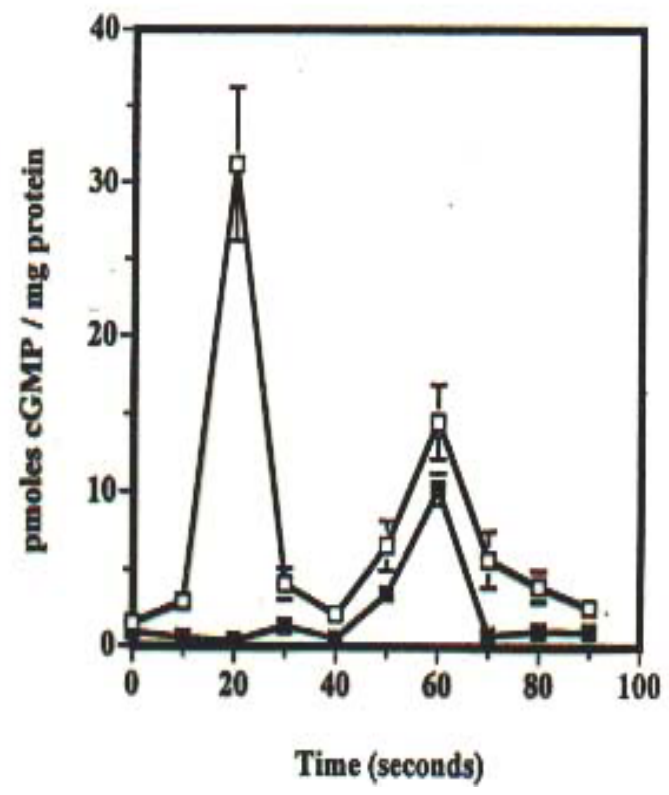

Effect of ODQ on the time course of cGMP signals induced by agonist muscarinic carbachol $\left(1 \times 10^{-5} \mathrm{M}\right)$ in TSM.

Tracheal smooth muscle strips were pre-incubated for $30 \mathrm{~min}$ with ODQ (1H-[1, 2,4 ] Oxadiazolo[4,3-a]quinoxalin-1one) (घ) (100 nM) selective inhibitor of NO-sGC, following the Procedure 2 as described in reference 36. Control experiments ( $\square$ ) without drug were run simultaneously under the same conditions. Each value is the mean \pm SE of 4 different tracheas and the cGMP determinations were carried out by triplicate as described in reference [36].

Figure 1. Time course of muscarinic agonist action on cGMP levels from TSM in the presence of ODQ. Taken from reference [36]. 
Interestingly, the 20-s signal is linked to the onset and the 60s signal is related to the plateau of the smooth muscle contraction as described in [36]. The 20-s signal is associated with the activity of a Soluble guanylyl cyclases, which are nitric oxide stimulated guanylyl cyclase (NO-sGC), which are described in [33] and the second, the 60-s signal, is linked to membrane-bound natriuretic peptide receptor guanylyl cyclase (NPR-GC) in references [33$35]$, which has been previously characterized at TSM in $[37,38]$.

The details of the activation of an NO-sGC, generating the early 20-s cGMP signal, presents in the plasma membrane of BTSM, has been previously established in reference [31].

Soluble guanylyl cyclases are nitric oxide stimulated guanylyl cyclase (NO-sGC) due to the fact that the primary and best-studied endogenous activator is nitric oxide (NO). NO-sGC is a heterodimeric hemoprotein formed by two different subunits, $\alpha$ - and $\beta$-subunits, which exist in four types $(\alpha 1, \alpha 2, \beta 1$, and $\beta 2)$, each the product of a separate gene as described in $[39,40]$. Structurally, each subunit consists of N-terminal H-NOX domain, a central domain related to the dimerization, and a C-terminal consensus nucleotide catalytic cyclase domain as described in [41,42]. For the formation of a catalytically active enzyme, both $\alpha$ - and $\beta$ subunits are required as reported in [43]. Although the $\alpha 1 \beta 1$ isoform is ubiquitous, the $\alpha 2 \beta 1$ isoform is less broadly distributed described in [39-43].

The best-characterized heterodimers are the $\alpha 1 / \beta 1$ and the $\alpha 2 / \beta 1$ isoforms as mentioned in [44] being the first ones, relevant in our studies as in [31]. At molecular level, His-105 at the amino terminus of the $\beta 1$ subunit of NO-sGC is the axial ligand of the pentacoordinated reduced iron center of heme, which is required for $\mathrm{NO}$ activation of the enzyme. Thus, NO activates SGC by binding to the sixth position of the heme ring, which breaks the bond between the axial histidine and iron to form a 5-coordinated ring with $\mathrm{NO}$ in the fifth position as reported in [45].

By using several experimental approaches as biochemical, pharmacological and molecular biology methods, we established that the first 20-s signal is a product of NO-sGC being sensitive to ODQ, as shown in Figure 2, which is translocated from cytoplasm to the inner face of the airway smooth muscle sarcolemma under muscarinic activation.

In addition, there is a coupling mechanism between $\mathrm{M}_{2} \mathrm{AChRs}$ and NO-sGC involving a $\mathrm{Go} / \mathrm{Gi}$ heterotrimeric proteins as previously demonstrated in [31]. Thus, in intact smooth muscle fragments and isolated plasma membranes from bovine tracheal smooth muscle, we showed that the heterodimer of NO-sGC involved in such translocation is the $\alpha 1 \beta 1$ sGC. The experimental evidence using Western blotting with specific antibodies against all subunits of NO-sGC demonstrate that under muscarinic activation, the $\alpha 1 \beta 1 \mathrm{NO}$-sGC-heterodimer isoform is translocated from cytoplasm to plasma membranes of BTSM. These experimental data are shown in Figure 3.

Since the capability of this $\alpha 1 \beta 1$-sGC to migrate to plasma membranes under muscarinic activation, a purification procedure and further identification of this $\alpha 1 \beta 1$-sGC heterodimer was also performed. Such NO-sGC translocation involves a $\mathrm{M}_{2} \mathrm{AChR}$ subtype as previously described in [31]. 


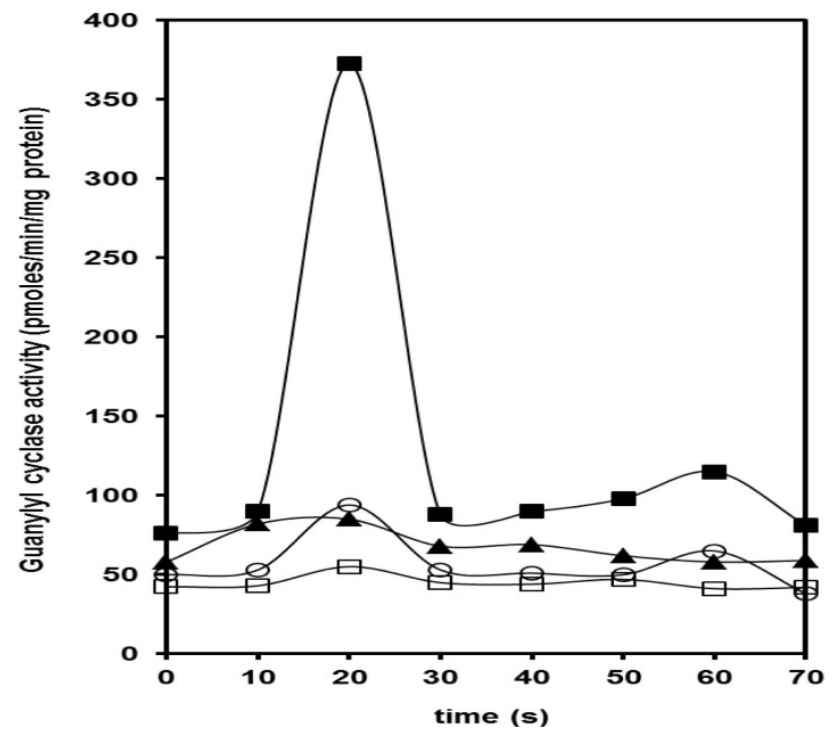

Isolated BTSM strips were incubated in KRB at 37C in the presence and absence of muscarinic agonist Cch $\left(1 \times 10^{-5} \mathrm{M}\right)$ for $70 \mathrm{sec}$ in [36]. After each $10 \mathrm{~s}$, the BTSM strips were removed and immediately frozen in liquid N2 and processed to prepare crude membranes fraction as described in [54]. In these membrane sediments, GC assays were performed in duplicate as described previously in [53]. Empty symbols represent GC assays performed by duplicate in the presence of $3 \mathrm{mM} \mathrm{MnCl2}, 0.2 \mathrm{M} \mathrm{GTP}, 5 \mathrm{mM}$ creatine phosphate, and $10 \mathrm{IU}$ phospho-creatine kinase in $0.01 \%$ defatted BSA. Full symbols represent GC activity in the presence of $100 \mu \mathrm{M}$ SNP. Basal ( $\square$ ), muscarinic agonist CC $1 \times 10^{-5} \mathrm{M}(\circ)$, basal plus SNP $(\boldsymbol{\Delta})$, and CC+SNP $(\boldsymbol{\bullet})$. Each value is the mean of three different BTSM strips.

Figure 2. Time-course of guanylyl cyclase activity in crude plasma membrane fractions isolated from BTSM strips under muscarinic agonist action. Taken from reference [31].

A.
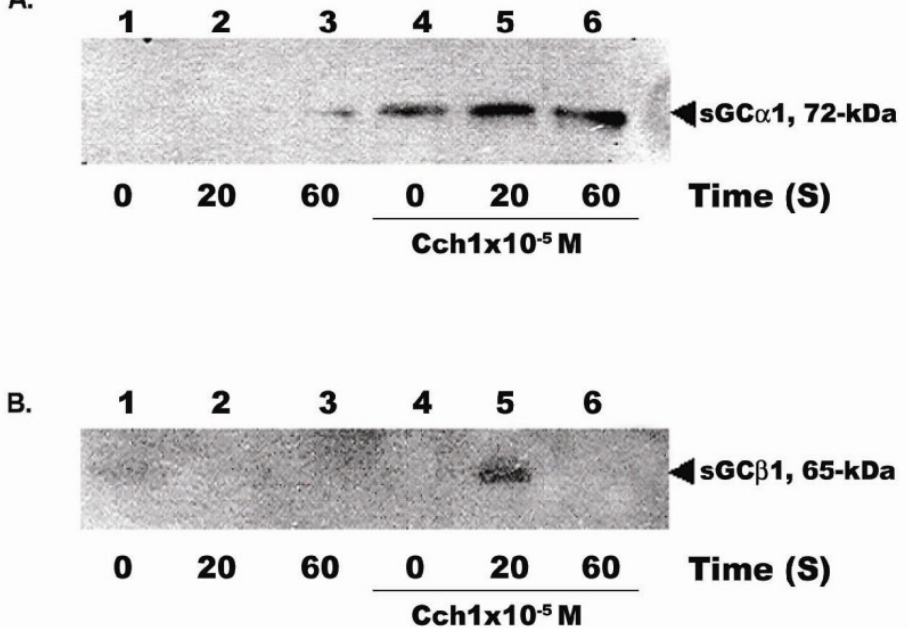

Figure 3. Western blotting of $\alpha 1 \beta 1$ NO-sGC-heterodimer from plasma membranes of BTSM under muscarinic activation as described in reference [31]. 
Identification of $\alpha 1 / \beta 1$ sGC heterodimer in membrane fractions isolated from BTSM strips under muscarinic agonist exposure. Isolated BTSM were incubated in KRB at $37^{\circ} \mathrm{C}$ in the presence and absence of muscarinic agonist CC $\left(1 \times 10^{-5} \mathrm{M}\right)$ during $0,20 \mathrm{~s}$ and $60 \mathrm{~s}$. The samples were immediately frozen and pulverized with a mortar in liquid nitrogen, following the protocols described to isolate crude plasma membranes fraction as described in $[31,54]$. The final membranes sediments were electrophoresed in 12\% PAGE-SDS, transferred to nitrocellulose membranes, and probed with specific antibodies against the $\alpha 1$, $\alpha 2$, (A) $\beta 1$ and $\beta 2$ (B) of NO-sGC subunits. The specific antibodies against $\alpha 2$ and $\beta 2$ produced negative results. This experiment was performed three times with similar results.

Thus, we demonstrate that the first 20-s cGMP signal is a product of a novel signaling cascade involving $\mathrm{M}_{2} \mathrm{AChR}$ coupled to Go/i proteins, which facilitates the $\alpha 1 \beta 1$-sGC isoform migration from cytoplasm to the BTSM sarcolemma. These experimental evidences support a model for the $\mathrm{M}_{2} \mathrm{AChR}, \mathrm{Gi} / \mathrm{o}$, and heterodimer of $\alpha 1 \beta 1$ of NO-sGC novel signal transducing cascade as illustrated in Figure 4.

\section{A. Basal}

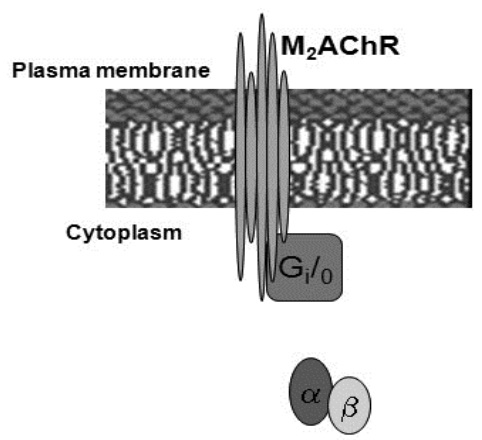

B. Muscarinic Agonist 20s

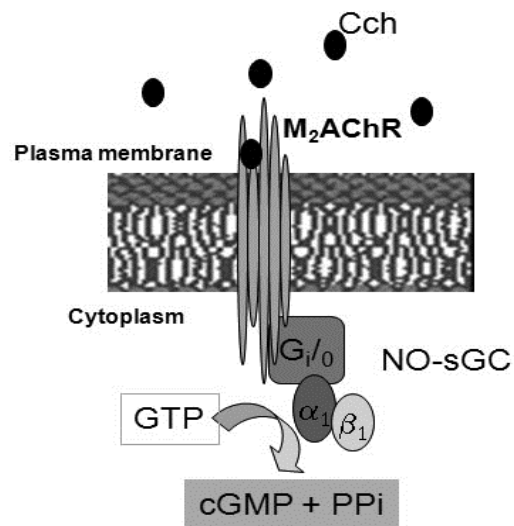

Figure 4. Model for the $\mathrm{M}_{2} \mathrm{AChR}, \mathrm{Gi} / \mathrm{o}$, and heterodimer of $\alpha 1 \beta 1$ of NO-sGC novel signal transducing cascade in mammalian cells taken from reference [31].

Proposed model for a novel signal transducing cascade in mammalian cells involving three distinct molecular entities: $\mathrm{M}_{2} \mathrm{AChR}, \mathrm{Gi} / \mathrm{o}$ protein, and heterodimer of $\alpha 1 \beta 1$ of NO-sGC. (A) Basal condition: The hetero-dimer $(\alpha 1 \beta 1 \mathrm{NO}-\mathrm{sGC})$ is located in the cytoplasm and the $\mathrm{M}_{2} \mathrm{AChR}$ and $\mathrm{Gi} / \mathrm{o}$ proteins are macromolecules spanning and associated respectively with the plasma membrane bilayer. (B) Under muscarinic exposure, the agonist (Cch) binds at the extracellular domains of $\mathrm{M}_{2} \mathrm{AChR}$ causing the activation of $\mathrm{M}_{2} \mathrm{AChR}$. This induces conformational changes at the $\mathrm{M}_{2} \mathrm{AChR}$ cytoplasm domains stimulating a PTX-sensitive $\mathrm{G}$ protein (Gi/o), which may induce a migration and further activation of the $\alpha 1 \beta 1$ heterodimer NOsGC from cytoplasm to the plasma membrane resulting in a fast rise in cGMP production, which is related to the 20-s cGMP signal generated during the muscarinic activation of tracheal smooth muscle cell. 
In the other hand, the 60-s cGMP signal is a product of a Natriuretic Peptide Receptor Guanylylcyclase-B (NPR-GC-B), which was previously identified at TSM, using biochemical as reported in [38] and molecular biology approaches as described in [37]. The NPR-GC-B (GC-B) is a membrane-spanning homodimer form, which contains an extracellular ligandbinding, trans-membrane, kinase homology, dimerization and carboxyl-terminal catalytic domains that was published in references [46,47]. NPR-GC-B, which is also called NPR-B or NPR2, is activated by CNP, which exists in 22 and 53 amino acid forms that are structurally similar to ANP and BNP as reported in references [48,49].

Furthermore, this GC-B from TSM is a novel G-protein coupled guanylyl cyclase presents in isolated plasma membranes fractions from this smooth muscle subtype as described in [53]. This G-protein-coupled NPR-GG-B showed complex kinetics and regulation, which is summarized in a proposed model as shown in Figure 5 as illustrated in reference [38]. This NPRB was activated by Natriuretic Peptides (CNP-53>CNP-22>ANP-28) at the Ligand Extracellular Domain, stimulated by Gq-protein activators such as mastoparan, and inhibited by a chloride sensitive-Gi/o, interacting at the Juxtamembrane Domain. The Kinase Homology Domain was evaluated by the ATP inhibition of $\mathrm{Mn}^{2+}$-activated-NPR-B, which was partially reversed by mastoparan. The Catalytic Domain was studied by its kinetics of $\mathrm{Mn}^{2+} / \mathrm{Mg}^{2+}$ and GTP, and the catalytic effect with GTP analogs with modifications of the $\beta \gamma$ phosphates and ribose moieties. Most NPR-B biochemical properties remained after detergent-solubilization but the mastoparan-activation and chloride-inhibition of NPR-B disappeared. This NPR-GC$\mathrm{B}$ is a highly regulated nano-machinery with domains acting at crosstalk points with other signal transducing cascades initiated by G-Protein Coupled Receptors (GPCR) and affected by intracellular ligands such as chloride, $\mathrm{Mn}^{2+}, \mathrm{Mg}^{2+}$, ATP and GTP. In addition, this model contains a novel GPRM domain, a G-protein-regulatory site, which was identified and characterized as the binding domain for the $G$ proteins subunits as described in [38].

GC-B is abundantly expressed in brain, lung, bone, heart and ovary tissue as reported in [50]. GC-B contains three intramolecular disulfide bonds and is highly glycosylated on asparagine residues. Moreover, GC-B is highly phosphorylated and dephosphorylation is associated with receptor inhibition as described in [51]. ATP increases the enzymatic activity of GC-B by reducing the Michaelis-Menten constant for GTP, an order of magnitude and this nucleotide seems to be essential for maximal activity as demonstrated in reference [52].

On the other hand, this Natriuretic Peptide Receptor Guanylylcyclase-B (NPR-GC-B), which has been previously identified as the predominant functional TSM membrane-bound GC subtype by using molecular biology in [37] and biochemical approaches as described in [38]. Nucleotide sequence of membrane-bound GC transcripts retrieved by RT-PCR correspond to the bovine GC-B isoform, indicating the predominance of this NPR-sensitive GC-B over GC-A and GC-C, which are also expressed in TSM in reference [37]. Both ANP and CNP stimulates the TSM membrane-bound GC activity in a concentration-dependent manner, but the CNP effect $\left(10^{-8}\right.$ to $\left.10^{-5} \mathrm{M}\right)$ was significantly higher than that exerted by ANP, whereas guanylin (a GC-C activator) showed no effect. Given that CNP specifically activates GC-B 
receptors and that it activates GC-A receptors only marginally, the significant CNP effect on TSM cGMP production indicates that NPR-GC-B is the most abundantly expressed tracheal membrane-spanning GC isoform, further confirming the RT-PCR results in [37].

\section{MODEL OF REGULATION OF A G-PROTEIN COUPLED GC-B}

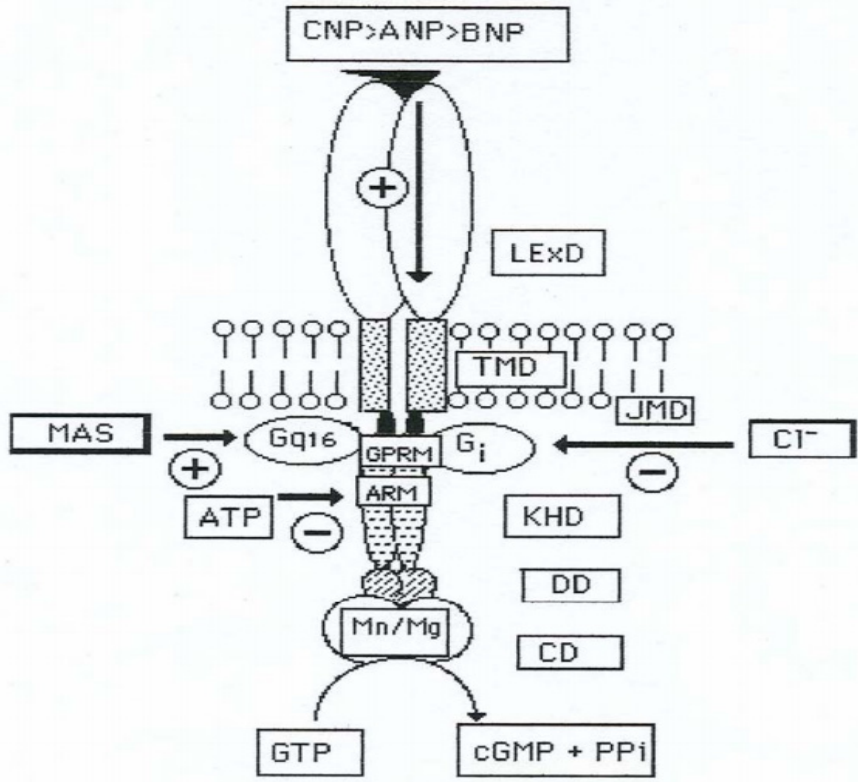

\footnotetext{
LExD: Ligand Extracellular Domain

TMD: Transmembrane Domain

JMD: Juxtamembrane Domain

KHD: Kinase Homology Domain

DD: Dimerization Domain

CD: Catalytic Domain

GPRM: G-Protein-Regulatory Module

ARM: ATP-Regulatory Module
}

Figure 5. Proposed model of the G-protein coupled NPR-GC-B as illustrated in reference [38].

This NPR-GC-B is regulated in an opposite way by two MAChRs signaling cascades, acting the $\mathrm{M}_{2} \mathrm{AChR}$ as an inhibitor and the $\mathrm{M}_{3} \mathrm{AChRs}$ as an activator of this NPR-GC-B as mentioned in [55].

This novel signal transducing system is illustrated as a model in Figure 6. The relevant feature of these two opposite signal cascades that regulate this NPR-GC-B is the coupling of two MAChRs and distinctive $G$ proteins. Thus, this activation system coupled a $\mathrm{M}_{3} \mathrm{AChR}$ to a Gq16 being stimulated by mastoparans (tetradecapeptides from wasp venoms), whereas, on the inhibitor cascade of NPR-GC-B, via $\mathrm{M}_{2} \mathrm{AChR}$ coupled to a Go/Gi protein has been previously described in references $[35,38,56]$. 


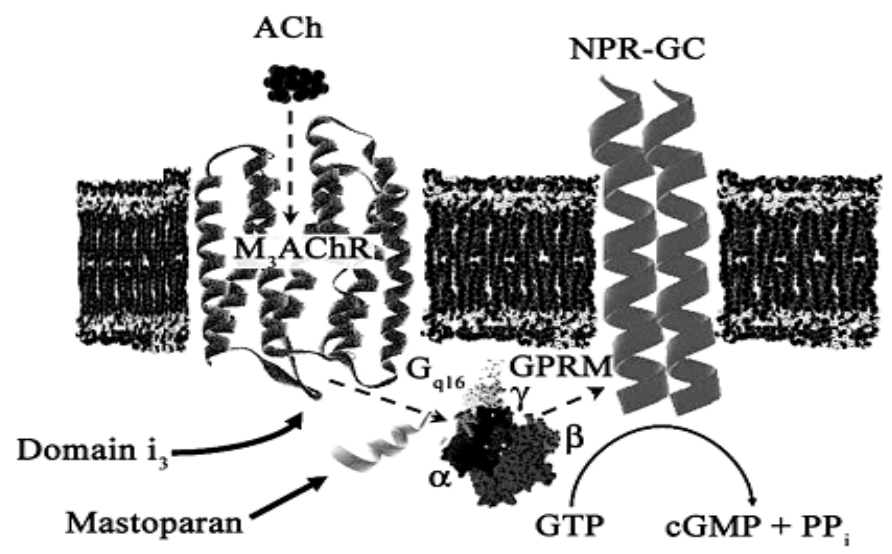

Figure 6. Schematic model of signal cascade involving m3AChR/Gq16/NPR-GC-B at BTSM in [56].

A model for coupling $\mathrm{M}_{3} \mathrm{AChR}$, via $\mathrm{Gq} \alpha{ }_{16} ß \gamma$ to activate NPR-GC-B in plasma membranes from BTSM. This model is composed of three separate and different molecular entities, $\mathrm{M}_{3} \mathrm{AChR}$, a GPCR seven transmembrane receptor, a heterotrimeric G protein and homodimeric NPR-GC (cGMP producing enzyme) as the effector. The drawings do not take into account the actual structural biology (molecular mass) of these entities; it is a scheme to suggest the flow of information in this novel signal transducing cascade, which is indicated by the dashed lines. Thus, a muscarinic agonist (ACh) binds at extracellullar domains of $\mathrm{M}_{3} \mathrm{AChR}$ inducing conformational changes at the cytoplasmic $\mathrm{i}_{3} \mathrm{M}_{3} \mathrm{AChR}$ domain, which stimulates the $\mathrm{Gq} \alpha_{16} ß \gamma$, to release its active subunits that interact with NPR-GC. Mastoparan and its active analogues may act at the interactions between $i_{3} \mathrm{M}_{3} \mathrm{AChR}$ domain and the $\mathrm{Gq} \alpha \alpha_{16} ß \gamma$ protein as indicated in the scheme.

Mastoparans are tetradecapeptides isolated from wasp venom as reported in $[57,58]$ and they are well known as heterotrimeric G-protein activators as described in [59,60]. Moreover, mastoparan is able to activate the NPR-GC-B associated with plasma membranes fractions from TSM in [56]. Following these results, we evaluate the effect of these peptides on TSM contraction. It was found that mastoparan and analogs were able to inhibit in a selective manner the BTSM contraction induced by muscarinic agonist as carbachol (CC) as shown in Figure 7. Thus, our original findings indicated that mastoparans in the $\mathrm{nM}$ range decreased the contractile maximal responses induced by CC without changing its $\mathrm{EC}_{50}$. One explanation for the decrement on the contractile maximal responses by mastoparans may be related to the ability of these tetradecapeptides to disturb the function and the contractile machinery of the BTSM type through cytotoxic mechanisms, which have been described in other biological models, specifically in the $\mu \mathrm{M}$ concentration range as described in $[61,62]$.

This assumption is not supported by our results on the effects of classic TSM spasmogens as 5-HT in as described in reference [63], which produced potent contractions even in the presence of mastoparan $(\mathrm{nM})$ as shown in Figure 8. These findings can be explained since this bioactive amine has been claimed to exert their physiological effects on TSM through 
specific GPCRs. These receptors are the 5-HT2A, which induced activation of the Gq/11 protein and its downstream effector phospholipase C (PLC) leading to intracellular phosphatidylinositol turnover and $\mathrm{Ca}^{2+}$ mobilization as reported in [64]. These $\mathrm{Gq} / 11$ proteins are mastoparan-insensitive ones. The latter facts can explain the mastoparaninsensitivity of the serotoninergic transducing cascades at TSM. Furthermore, our results demonstrated that mastoparan inhibits selectively the muscarinic activation without altering other spasmogens transducing cascades at TSM.

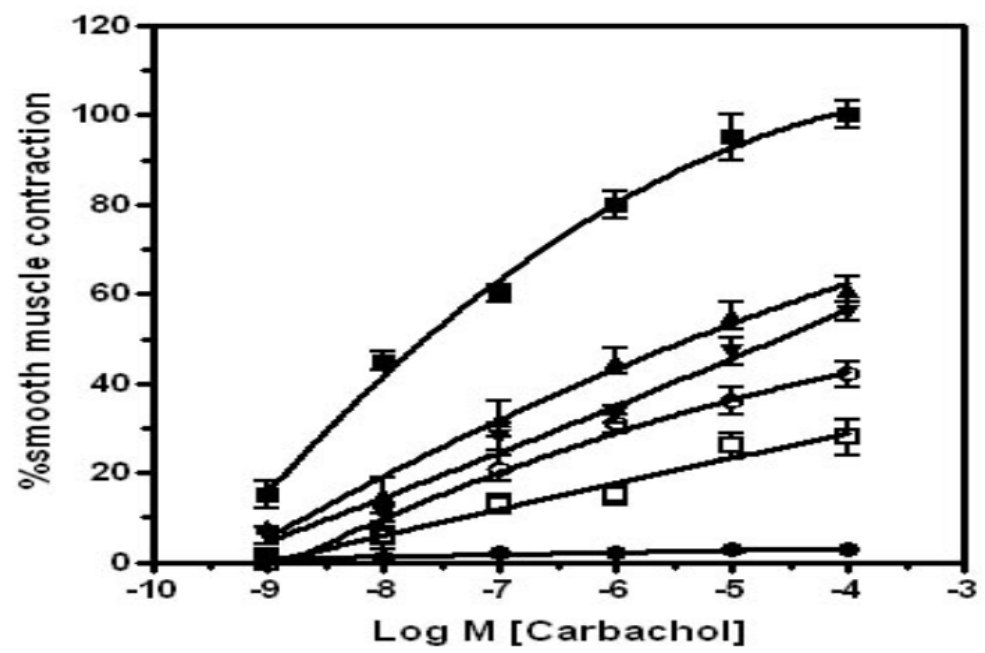

The BTSM strips contractile activity was measured using Procedure 1 as previously described in [36]. Carbachol cumulative responses using concentrations from $1 \times 10^{-9} \mathrm{M}$ to $1 \times 10^{-4} \mathrm{M}$ were measured in recording period until $3 \mathrm{~min}$. Mastoparan was pre-incubated for $10 \mathrm{~min}$ before the muscarinic agonist (carbachol) addition. Experimental conditions: (घ) Control, ( $(\boldsymbol{\Delta}) 0.5 \mathrm{nM}(\boldsymbol{\nabla}) 1 \mathrm{nM}(\circ) 5 \mathrm{nM}(\square) 10 \mathrm{nM}(\bullet)$ 50nM. The maximal contractile activity was considered as $100 \%(3.2 \pm 0.2 \mathrm{~g})$ and this value was used to estimate other contractile responses. Each value is the mean $\pm \mathrm{SEM}$ of three different tracheas assayed in duplicate.

Figure 7. Carbachol cumulative concentration curves responses from BTSM, pre-treated with mastoparan.

From the data above mentioned, mastoparan can affect specifically the signal cascades associated with the muscarinic activation at TSM sarcolemma, which are initiated with a $\mathrm{mAChRs}$ coupled to heterotrimeric G-proteins in reference [65]. These results indicate that the most like candidates implicated in mastoparan effects are the heterotrimeric G-proteins coupled to these mAChRs. G protein involvement on the mastoparan inhibition on TSM muscarinic activation is supported by the ability of this G-protein activator to alter the generation of the two GMPc signals at 20-s and 60-s as previously described in [36]. Mastoparan $(50 \mathrm{nM})$ induced a potent inhibition of these cGMP signals, as shown in Figure 8. After mastoparan pre-incubation, the kinetics of cGMP intracellular levels at TSM was evaluated following the muscarinic agonist exposure. Interestingly, the first cGMP signal (20-s) decreased in more than $60 \%$ and the second signal peak (60-s) completely vanished. 
The disappearance of the second signal of cGMP (60-s) correlates well with a significant reduction on the contractile maximal responses as here described in Figure 7. This 60-s cGMP signal is a product of NPR-GC-B as above mentioned in references [35,54,55]. Recently, we further recognized that muscarinic agonist and mastoparan activations of NPR-GC-B in isolated BTSM plasma membranes fraction involve this mastoparan-sensitiveGq16 protein in [54]. Thus, the pre-exposure of TSM strips to mastoparan stimulated the Gq16 protein, disrupting this signal cascade inducing the failure of this muscarinic-dependent TSM contraction. However, the serotoninergic-dependent TSM contraction remained functionally active indicating that the smooth muscle machinery remains fully active.

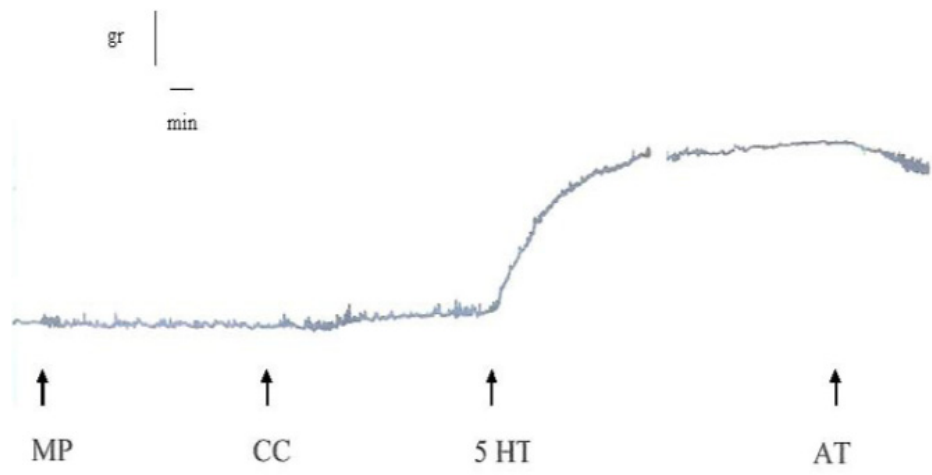

BTSM fragments were stabilized for $1 \mathrm{~h}$ using a procedure described previously in [36]. Later, mastoparan (50 $\mathrm{nM})$ was added for $10 \mathrm{~min}$, followed by carbachol (CC) $\left(1 \times 10^{-4} \mathrm{M}\right)$, serotonin or 5-hydroxytryptamine (5-HT) $\left(1 \times 10^{-4} \mathrm{M}\right)$ and Atropine (AT) $\left(1 \times 10^{-4} \mathrm{M}\right)$ was added. Values between parentheses are the final concentration of drugs in the incubation media. This trace is representative of 3 experiments performed with 3 different tracheas fragments.

Figure 8. Serotonin (5HT) induced contractile responses in mastoparan-treated BTSM strips.

Until now, the BTSM muscarinic activation is unique biological system that involves two cGMP signals as second messengers in references [35,36]. In addition, this activation is a highly regulated biological process, which starts with $\mathrm{M}_{2} / \mathrm{M}_{3} \mathrm{AChRs}$ coupled to two different heterotrimeric $G$ proteins, leading to a fine time regulation and stimulation of two distinctive guanylyl cyclases that accomplish the generation of these two (20-s and 60-s) cGMP signal peaks.

Based in our results, it can be postulated that the first cGMP signal (20-s) is a product of the activation of one $\mathrm{M}_{2} \mathrm{AChR}$ subtype coupled to a PTX-sensitive-Gi/o protein that leads to the translocation and further activation of the heterodimer $\alpha 1 \beta 1$ NO-sGC isoform, anchored to plasma membrane. Recently, it has been suggested that a plasma membrane-bound GC, may provide a localized pool of cGMP in [68], which seems to be in a similar trend suggested by our work. The second signal peak is a product of a the activation of $\mathrm{M}_{3} \mathrm{AChR}$ coupled to the stimulation of mastoparan-sensitive Gq16 as reported in reference [54] to turn on a transmembrane-homodimer as NPR-GC-B as described in [35,55]. 


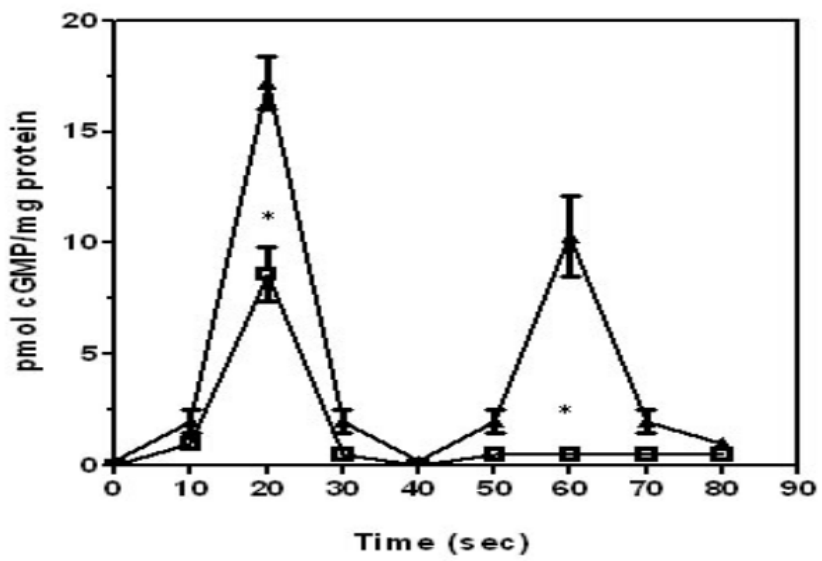

BTSM strips were assayed using following Procedure 2 as described in [36]. Pre-incubation for 10 min with mastoparan ( $\square)(50 \mathrm{nM})$ was performed. Control experiments $(\boldsymbol{\Delta})$ without drugs were run simultaneously under the same conditions. Each value is the mean $X \pm S E M$ of four different tracheas, and the cGMP determinations were carried out in triplicate as described in references [36,53]. Statistically significant difference between the Control with respect to mastoparan as indicated with asterisk $\left({ }^{*} p<0.05\right)$.

Figure 9. Mastoparan effect on cGMP signal peaks induced by muscarinic agonist (carbachol) in TSM.

Thus, a dysfunction of these $\mathrm{M}_{2} / \mathrm{M}_{3} \mathrm{AChR}$ signal transducing cascades has been implied in the pathophysiological mechanisms of bronchial asthma as mentioned in references $[1,3,4]$ and Chronic Obstructive Pulmonary Disease (COPD) in [3]. In this sense, we attempted to evaluate these novel signal transducing cascades involving guanylyl cyclase activities above discussed, in an experimental asthma model in rats as described in reference [70]. In addition, it has been claimed that excessive NO production that occurs in asthma induces a down-regulation of NO-sGC as reported in [69].

Following these rationale, we used cultured Airway Smooth Muscle Cells (ASMC) from Control and an experimental asthma model (Ovoalbumin exposed rats or OVA-ASMC), which were sensitized to Ovoalbumin using a procedure described in [70,71]. In these ASMC, we evaluate the cGMP production by NPR-GC-B stimulated by muscarinic agonists, mastoparans, natriuretic peptides (ANP, CNP) and for NO-sGC, a classic NO donor as Sodiun NitroPrusside (SNP) and a selective inhibitor for the NO-sGC as $1 \mathrm{H}-[1,2,4]$ Oxadiazolo[ 4,3-a]quinoxalin-1-one (ODQ) were used.

All ASMC exposed to a NO-donor compound as SNP and muscarinic agonist as CC increased cGMP intracellular levels, which were inhibited by ODQ, suggesting that NO-sGC is present and this activity is partially responsible for cGMP production in these ASMC. However, OVA-ASMC showed low basal cGMP production compared to CONTROL ASMC in reference [71] as shown in Figure 10 possibly due to substantial reduced NO-sGC expression reflected in decrease the steady state levels of NO-sGC subunit mRNAs and protein level expression, as described in intact lung tissue from OVA-sensitized mice described elsewhere in reference [69]. 


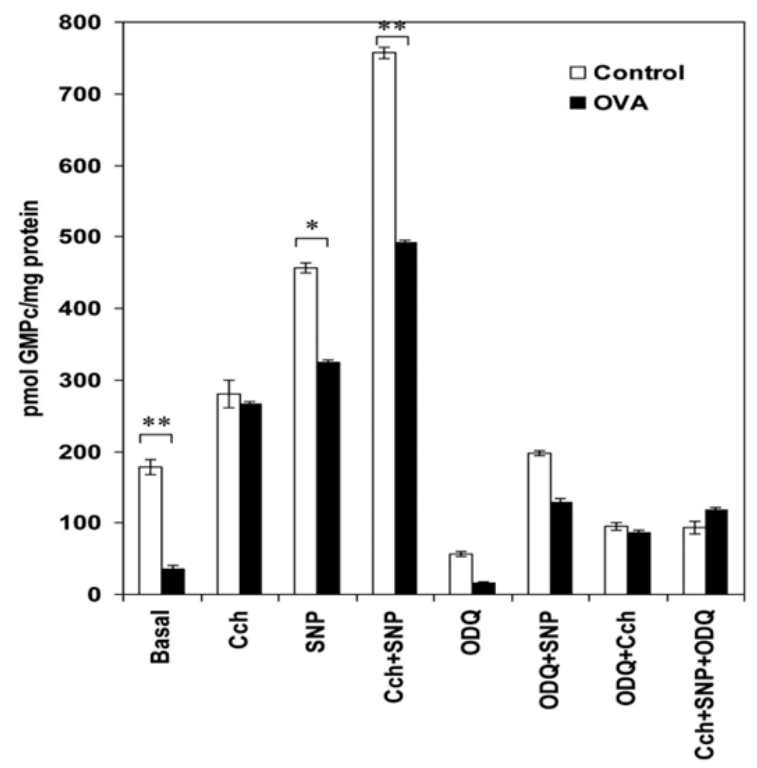

Cyclic GMP (cGMP) production in airway smooth muscle cells (ASMC) from CONTROL and OVA- sensitized rats. The ASMC were incubated for $15 \mathrm{~min}$ in the presence of IBMX as described in reference [70]. Cyclic GMP production was determined in the presence of Cch, SNP and ODQ as described in Methods. The cGMP produced was estimated by duplicate using a radioimmunoassay kit from Amersham as described in [70]. Each value is the mean \pm of 5 different experiments. In both groups, the amounts of cell cultures plates were obtained for a pool of 5 rats. The stadistical significance between CONTROL vs OVA was established as $p<0.05\left(^{*}\right)$ and $p<0.001\left(^{* *}\right)$.

Figure 10. The effect of NO-sGC activators and inhibitors on total GC activity from Control and OVA ASMC. Taken from reference [70].

Trying to understand the role of the NPR-GC-B in the ASMC, we studied the effect of several activators of this NPR-GC such as natriuretic peptides (ANP and CNP) and mastoparans as previously described in BTSM in references [37,38,71]. Thus, ASMC from Control and OVA-exposed rats were cultured and exposed to these NPR-GC-B activators. Thus, in Figure 11, the total GC activity at OVA-ASMC was stimulated by CNP, ANP and muscarinic agonist (Cch) indicating that NPR-GC-B was present in Control ASMC, which are similar results described in intact BTSM strips and isolated plasma membranes from BTSM in references $[37,38,53,55]$. In addition, the OVA-ASMC showed a more significant stimulation by these NPR-GC activators. Interestinly, the combination of CC plus ANP and CNP increased in more than 6 times the GC activity. As expected, mastoparan, an activator of NPR-GC-B, via Gq16 dramatically increased in 5 times, the GC activity as reported in [72]. These data showed for the first time that there is an hyperstimulation of $\mathrm{M}_{3} \mathrm{AChR} / \mathrm{Gq} 16 / \mathrm{NPR}-\mathrm{GC}-\mathrm{B}$ cascade in ASMC from a experimental asthma model.

Taking together all these results indicate that the ASMC from OVA-sensitized rats express a reduced NO-sGC activity and an increased in the NPR-GC-B activity. This imbalance between these two guanylyl cyclases can contribute to airway hyperreactivity and might be implicated in the hyperplastic smooth muscle responses and remodeling present in asthma. 
All these previous experimental data unravels some of complex molecular mechanisms associated with the muscarinic activation of ASM. This muscarinic activation is the most physiological, pathophysiological and pharmacological relevant mechanisms because Ach is the neurotransmitter-linked stimulation of ASM in asthma and COPD. Thus, this works opens new trends for the pathophysiological and pharmacological mechanisms, which may lead to new therapeutic approaches for the treatment of these chronic respiratory diseases, such as asthma and COPD, in which, the ASM is involved.

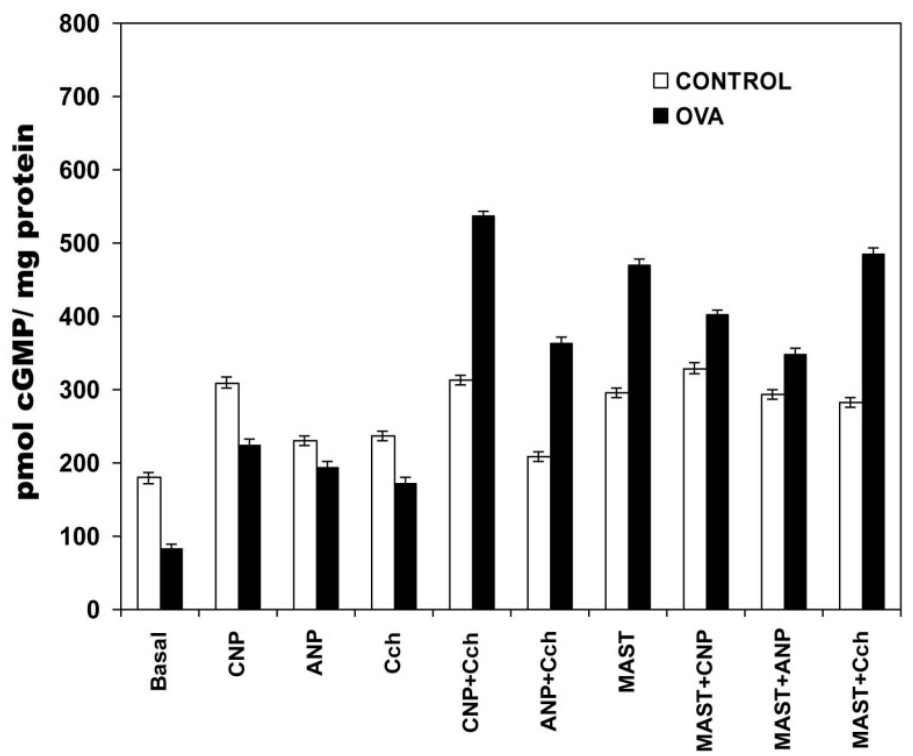

The effect of NPR-GC activators on total GC activity in Control and OVA ASMC. The OVA and Control ASMC were incubated for $15 \mathrm{~min}$ in the presence of $100 \mu \mathrm{M}$ IBMX (non-selective PDEs inhibitor). Cyclic GMP production was determined in the presence of Cch $\left(1 \times 10^{-5} \mathrm{M}\right)$, Mastoparan $\left(1 \times 10^{-7} \mathrm{M}\right), \mathrm{CNP}\left(1 \times 10^{-7} \mathrm{M}\right)$ and ANP $\left(1 \times 10^{-7} \mathrm{M}\right)$. The reaction was stopped by removing the medium immediately and freezing with liquid $\mathrm{N}_{2}$ was later $500 \mu \mathrm{l}$ of TCA $6 \%$, mixed vigorously and centrifuged for $1,500 \mathrm{~g}$ x $15 \mathrm{~min}$. The acid extract was treated 2 times with ether saturated with water and the water phase was then lyophilized and suspended in $0.150 \mathrm{ml}$ of water. The cGMP produced by these cells were determined using a radioimmunoassay kit as previously described in reference [70].

Figure 11. The effect of NPR-GC activators on total GC activity in Control and OVA ASMC.

\section{Conclusion}

In this review, we exposed the recent experimental evidences, in relation to the generation of cGMP, on the muscarinic activation of ASM, which is the essential element in the bronchoconstriction presents in asthma.

Moreover, this muscarinic activation seems to be involved in the remodelling and functional changes of ASM described in asthma and COPD as described in references [1-6,73]. We discussed the existence of two cGMP signals, at 20-s and 60-s in [36], which are products of two distinctive guanylyl cyclases, the NO-sensitive soluble guanylyl cyclases (NO-sGC) and 
Natriuretic Peptide Receptor Guanylyl Cyclase-B (NPR-GC-B). The 20-s cGMP signal is linked to the activation of a $\mathrm{M}_{2} \mathrm{AChR}$ coupled to $\mathrm{Go} / \mathrm{Gi}$ proteins inducing a massive and transient $\alpha 1 \beta 1-\mathrm{NO}-\mathrm{sGC}$ translocation from cytoplasm to plasma membranes of ASM as reported in [31].

The 60-s cGMP signal is associated with a NPR-GC-B in [37], a novel G-protein coupled NPR-GC-B as described in references [38,53,55], which is nano-machine regulated by GPCR and also modulated, in an opposite way, by an activator M3AChRs coupled to Gq16 to activate NPR-GC-B (M3AChR/Gq16/NPR-GC-B cascade) that is stimulated by mastoparan as reported in [56] and an inhibitor $\mathrm{M}_{2} \mathrm{AChR}$ signal cascade that was partially characterized.

Mastoparan inhibited in a selective manner the muscarinic-dependent ASM contraction and affected the two cGMP signals. The ASM muscarinic activation is unique biological system involving two cGMP signals and a dysfunction of these $\mathrm{M}_{2} / \mathrm{M}_{3} \mathrm{AChR}$ cascades has been implied in asthma and COPD as published in references [1-6].

We used another mammalian model as ASM from rats, which are more prone to develop experimental asthma using Ovoalbumin leading to the OVA-sensitized rats model as described in [70,71]. In isolated and cultured Airway Smooth Muscle Cells (ASMC) from Control and OVA, we evaluated the cGMP production in these ASM cultured cells. All ASMC showed cGMP increments by a classic NO donor as SNP being ODQ-sensitive, indicating that NO-sGC is present, but OVA-ASMC showed low basal cGMP production compared to Control ASMC described in [71], which confirmed the molecular biology results reported elsewhere in reference [69]. Moreover, NPR-GC-B is present in Control ASMC but OVA ASMC displayed an hyperstimulation of $\mathrm{M}_{3} \mathrm{AChR} / \mathrm{Gq} 16 / \mathrm{NPR}-\mathrm{GC}-\mathrm{B}$ cascade, which is an original experimental findings as reported in [72].

These results indicate that the OVA-ASMC express a reduced NO-sGC and increased NPRGC-B activities. This imbalance between these two GCs can contribute to airway hyperreactivity and might be implicated in the abnormal ASM responses present in asthma and COPD.

\section{Author details}

Marcelo J. Alfonzo, Fabiola Placeres-Uray, Walid Hassan-Soto, Adolfo Borges, Ramona González de Alfonzo and Itala Lippo de Becemberg Sección de Biomembranas, Instituto de Medicina Experimental Facultad de Medicina, Universidad Central de Venezuela, Apdo, Sabana Grande, Caracas, Venezuela

\section{Acknowledgement}

This work was supported by grants from CDCH-UCV \# PG -09-7401-2008/2 (RGA) and CDCH-UCV \# PI -09-7726.2009/2 (ILB) and financial support for the publication of this book chapter. WHS is a Graduate student at Ph-D program of Curso de Postgrado en Ciencias 
Fisiológicas. Facultad de Medicina, Universidad Central de Venezuela (UCV). The authors thank to Dr. Marcelo Alfonzo-González for the editing process of this manuscript.

\section{References}

[1] Belmonte KE. Cholinergic pathways in the lungs and anticholinergic therapy for chronic obstructive pulmonary disease. Proc Am Thor Soc. 2005; 2: 297-304.

[2] Van der Velden VH, Hulsmann AR. Autonomic innervation of human airways: structure, function, and pathophysiology in asthma. Neuroimmunomodulation 1999; 6: 14559.

[3] Gosens R, Zaagsma J, Meurs H, Halayko AJ. Muscarinic receptor signaling in the pathophysiology of asthma and COPD. Resp Res 2006; 7: 73-86.

[4] Racké K, Matthiesen S. The airway cholinergic system: physiology and pharmacology. Pulm Pharmac Ther. 2004; 17: 181-198.

[5] Racké K, Juergens UR, Matthiesen S. Control by cholinergic mechanisms. Eur J of Pharmacol. 2006; 533: 57-68.

[6] Proskocil BJ, Sekhon HS, Jia Y, Savchenko V, Blakely RD, Lindstrom J, Spindel ER. Acetylcholine is an autocrine or paracrine hormone synthesized and secreted by airway bronchial epithelial cells. Endocrinology 2004; 145: 2498-2506.

[7] Wessler I, Kirkpatrick CJ. Acetylcholine beyond neurons: the non-neuronal cholinergic system in humans. Br J Pharmacol. 2008; 154:1558-1571.

[8] Wessler IK, Kirkpatrick CJ. The non-neuronal cholinergic system: an emerging drug target in the airways. Pulmonary Pharmacol Ther. 2001; 14: 423-434.

[9] Gosens D, Rieks H, Meurs DK, Ninaber, KF, Rabe K, J. Nanninga J, Kolahian S, Halayko AJ, Hiemstra PS, Zuyderduyn S. Muscarinic M3 receptor stimulation increases cigarette smoke-induced IL-8 secretion by human airway smooth muscle cells. Europ Resp. 2009; J 34: 1436-1443

[10] Tliba O, Panettieri RA. Noncontractile functions of airway smooth muscle cells in asthma. Ann. Rev. Phys. 2009; 71: 509-535.

[11] Challiss RA, Adams D, Mistry R, Boyle JP. Second messenger and ionic modulation of agonist-stimulated phosphoinositide turnover in airway smooth muscle. Biochem Soc Trans. 1993; 21:1138-1145.

[12] Oldhman WM, Hamm HE. Heterotrimeric G protein activation by G-protein-coupled receptors. Nat Rev Mol Cell Biol. 2008; 9: 60-71.

[13] Kotenis E, Zeng FY, Wess J. Structure-function of muscarinic receptors and their associated G proteins. Life Sci. 1999; 64: 335-362.

[14] Caufield MP. Muscarinic receptors-characterization, coupling and function. Pharmacol Ther. 1993; 58: 319-379.

[15] Maeda A, Kubo T, Mishina M, Numa S. Tissue distribution of mRNAs encoding muscarinic acetylcholine receptor subtypes. FEBS Lett. 1998; 239: 339-342.

[16] Lucchesi PA, Scheid CR, Romano FD, Kargacin ME, Mullikin-Kilpatrick D, Yamaguchi $\mathrm{H}$, Honeyman TW. Ligand binding and G protein coupling of muscarinic receptors in airway smooth muscle. Am J Physiol. 1990; 258: C730-738. 
[17] Eglen RM, Hedge SS, N. Watson N. Muscarinic receptor subtypes and smooth muscle function. Pharmacol Rev.1996; 48: 531-565.

[18] Roffel, AF, Elzinga CRS, Van Amsterdam RGM, De Zeueuw RA, Zaagsma J. Muscarinic receptors in bovine tracheal smooth muscle: Discrepancies between binding and function. Eur J Pharmacol. 1988; 153:73-82

[19] Misle AJ, Bécemberg IL, Alfonzo RG, Alfonzo MJ. Methoctramine binding sites sensitive to alkylation on muscarinic receptors from tracheal smooth muscle. Biochem Pharmacol. 1994; 48: 191-195.

[20] Misle A, Bruges G, Herrera VN, Alfonzo MJ, Becemberg IL, Alfonzo, RG. G-proteindependent antagonists binding in M3 AChR from tracheal smooth muscle. Arch Venez Farm Terap. 2001; 20:144-152.

[21] Meurs H, Roffel AF, Postema JB, Timmermans A, Elzinga, CRS, Kauffman, HF, Zaagsma J. Evidence for a direct relationship between phosphoinositide metabolism and airway smooth muscle contraction induced by muscarinic agonists. Eur J Pharmacol.1988; 156: 271-274.

[22] Roffel AF, Elzinga CR, Zaagsma J. Muscarinic $\mathrm{M}_{3}$ receptors mediate contraction of human central and peripheral airway smooth muscle. Pulm Pharmacol. 1990; 3: 47-51

[23] Grandordy BM, Cuss FM, Sampson AS, Palmer JB, Barnes PJ. Phosphatidylinositol response to cholinergic agonists in airway smooth muscle: relationship to contraction and muscarinic receptor occupancy. J Pharmacol Exp Ther. 1986; 238:273-279.

[24] Roffel AF, Meurs H, Elzinga CR, Zaagsma J. Characterization of the muscarinic receptor subtype involved in phospho-inositide metabolism in bovine tracheal smooth muscle. Br J Pharmacol. 1990; 99: 293-296.

[25] Jones CA, Madison JM, Tom-Moy M, Brown JK. Muscarinic cholinergic inhibition of adenylate cyclase in airway smooth muscle. Am J Physiol. 1987; 253:C97-104.

[26] Sankary RM, Jones CA, Madison JM, Brown JK. Muscarinic cholinergic inhibition of cyclic AMP accumulation in airway smooth muscle. Role of a pertussis toxin-sensitive protein. Am Rev Respir Dis. 1988; 138:145-150.

[27] Fernandes LB, Fryer AD, Hirshman CA. M2 muscarinic receptors inhibit isoproterenolinduced relaxation of canine airway smooth muscle. J. Pharmacol Exp Ther. 1992; 262, $119-126$.

[28] Zhou XB, Wulfsen I, LutzS, Utku E, Sausbier U, Ruth P, Wieland T, Korth M M2 Muscarinic Receptors Induce Airway Smooth Muscle Activation via a Dual, G $\beta \gamma$-mediated Inhibition of Large Conductance Ca2+-activated K Channel Activity. J Biol Chem. 2008; 283: 21036-21044.

[29] Semenov I, Wang B, Herlihy JT, Brenner R. BK channel $\beta 1$ subunits regulate airway contraction secondary to $\mathrm{M}_{2}$ muscarinic acetylcholine receptor mediated depolarization. J Physiol. 2011; 589.7: 1803-1817.

[30] Nakahara T, Yunoki M, Mitani A, Sakamoto K, Ishii K. Stimulation of muscarinic $\mathrm{M}_{2}$ receptors inhibits atrial natriuretic peptide-mediated relaxation in bovine tracheal smooth muscle. Naunyn Schmiedebergs Arch Pharmacol. 2002; 366: 376-379.

[31] Uray FP, de Alfonzo RG, de Becemberg IL, Alfonzo MJ. Muscarinic agonists acting through M2 acetylcholine receptors stimulate the migration of an NO-sensitive guan- 
ylyl cyclase to the plasma membrane of bovine tracheal smooth muscle. J Recept Signal Transduct Res. 2010, 30:10-23.

[32] Katsuki S, Murad F. Regulation of adenosine cyclic 3',5'-monophosphate and guanosine cyclic 3',5'-monophosphate levels and contractility in bovine tracheal smooth muscle. Mol Pharmacol. 1977;13: 330-341.

[33] Potter LR. Guanylyl cyclase structure, function and regulation. Cellular Signalling 2011; 23:1921-1926.

[34] Potter LR, Abbey-Hosch S, Dickey DM. Natriuretic peptides, their receptors, and cyclic guanosine monophosphate-dependent signaling functions. Endocr Rev. 2006, 27: 47-72.

[35] Alfonzo MJ, Guerra LG., Villarroel SS, Toba GF, Misle A, Herrera VN, Alfonzo RG, Lippo IB. Signal transduction pathways through mammalian guanylyl cyclases New Advances in Cardiovascular Physiology and Pharmacology 1998; 147-175.

[36] González LG, A. Misle A, G. Pacheco G, Herrera VN, Alfonzo RG, Bécemberg IL, and M.J. Alfonzo MJ. Effects of 1H-[1, 2, 4] Oxadiazolo[4, 3, $\alpha$ ] quinoxalin-1-one (ODQ) and $\mathrm{N}^{\oplus}(6)$-nitro-L-arginine methylester (NAME) on cyclic GMP levels during muscarinic activation of tracheal smooth muscle. Biochem Pharmacol. 1999; 58: 563-569.

[37] Borges A, de Villarroel SS, Winand NJ, de Bécemberg IL, Alfonzo MJ, de Alfonzo RG. Molecular and biochemical characterization of a CNP-sensitive guanylyl cyclase in bovine tracheal smooth muscle. Am J Respir Cell Mol Biol. 2001; 25: 98-103.

[38] Alfonzo MJ, de Aguilar EP, de Murillo AG, de Villarroel SS, de Alfonzo RG, Borges A, de Becemberg IL. Characterization of a G-protein coupled guanylyl cyclase-B receptor from Bovine Tracheal Smooth Muscle. J Recept Signal Transduct Res. 2006; 26: 269-297.

[39] Sharina IG, Krumenacker JS, Martin E, Murad F. Genomic organization of $\alpha 1$ and $\beta 1$ subunits of the mammalian soluble guanylyl cyclase genes. Proc Natl Acad Sci (USA) 2000; 97:10878-10883.

[40] Jiang Y, Stojilkovic SS. Molecular cloning and characterization of soluble of alpha1soluble guanylyl cyclase gene promoter in rat pituitary cells. J Mol Endocrinol. 2006; 37:503-515.

[41] Pyriochou A, Papapetropoulos A. Soluble guanylyl cyclase: more secrets revealed. Cell Signal 2005; 17:407-413.

[42] Wedel B, Harteneck C, Foerster J, Friebe A, Schultz G, Koesling D. Functional domains of soluble guanylyl cyclase. J Biol Chem. 1995; 270: 24871-24875.

[43] Buechler WA, Nakane M, Murad F. Expression of soluble guanylate cyclase activity requires both enzyme subunits. Biochem Biophys Res Commun. 1991;174: 351-357.

[44] Wagner C, Russwurm M, Jäger R, Friebe A, Koesling D. Dimerization of nitric oxidesensitive guanylyl cyclase requires the alpha $1 \mathrm{~N}$ terminus. J Biol Chem. 2005; 280:17687-17693.

[45] Russwurm M, Koesling D. NO activation of guanylyl cyclase. EMBO J. 2004; 10: 44434450.

[46] Sunahara RK, Beuve A, Tesmer JJ, Sprang SR, Garbers DL, Gilman AG. Exchange of substrate and inhibitor specificities between adenylyl and guanylyl cyclases. J Biol Chem. 1998; 273:16332-16338. 
[47] Tucker CL, Hurley JH, Miller TR, Hurley JB. Two amino acid substitutions convert a guanylyl cyclase, RetGC-1, into an adenylyl cyclase. Proc Natl Acad Sci (USA). 1998; 95: 5993-5997.

[48] Suga S, Nakao K, Hosoda K, Mukoyama M, Ogawa Y, Shirakami G, Arai H, Saito Y, Kambayashi $Y$, Inouye K. Receptor selectivity of natriuretic peptide family, atrial natriuretic peptide, brain natriuretic peptide, and C-type natriuretic peptide. Endocrinology 1992; 130: 229-239.

[49] Koller KJ, Lowe DG, Bennett GL, Minamino N, Kangawa K, Matsuo H, Goeddel DV. Selective activation of the B natriuretic peptide receptor by C-type natriuretic peptide (CNP). Science 1991; 252:120-123.

[50] Nagase M, Katafuchi T, Hirose S, Fujita T. Tissue distribution and localization of natriuretic peptide receptor subtypes in stroke-prone spontaneously hypertensive rats. J Hypertens. 1997; 15:1235-43.

[51] Potter LR, Hunter T. Identification and characterization of the major phosphorylation sites of the B-type natriuretic peptide receptor. J Biol Chem. 1998; 273:15533-15539.

[52] Antos LK, Potter LR. Adenine nucleotides decrease the apparent $\mathrm{Km}$ of endogenous natriuretic peptide receptors for GTP. Am J Physiol Endocrinol Metab. 2007; 293:E17561763.

[53] Lippo de Bécemberg I, Correa de Adjounian MF, Sánchez de Villaroel S, Peña de Aguilar E, González de Alfonzo R, Alfonzo MJ. G-protein-sensitive guanylyly cyclase activity associated with plasma membranes. Arch Biochem Biophys. 1995; 324:209-215.

[54] Alfonzo RG, Becemberg IL, Alfonzo MJ. A Ca2+/CAM protein kinase associated with Ca2+ transport in sarco(endo)plasmic vesicles from tracheal smooth muscle. Life Sci. 1996; 58:1403-1412.

[55] Alfonzo MJ, de Bécemberg IL, de Villarroel SS, de Herrera VN, Misle JA, de Alfonzo RG Two opposite signal transducing mechanisms regulate a $G$ protein coupled guanylyl cyclase. Arch Biochem Biophys. 1998; 350: 19-25.

[56] Bruges G, Borges A, Sánchez de Villarroel S, Lippo de Bécemberg I, Francis de Toba G, Pláceres F, González de Alfonzo R, Alfonzo MJ. Coupling of M3 acetylcholine receptor to Gq16 activates a natriuretic peptide receptor guanylyl cyclase. J Recept Signal Transduct Res. 2007; 27:189-216.

[57] Hirai Y, Yasuhara T, Yoshida H, Nakajima T, Fujino M, Kitada C. A new mast cell degranulating peptide "mastoparan" in the venom of Vespula lewisii. Chem Pharm Bull (Tokyo) 1972; 27: 1942-1944.

[58] Higashijima T, Uzu S, Nakajima T, Ross E. Mastoparan a peptide toxin from wasp venom, mimics receptors by activating GTP-binding regulatory proteins ( $\mathrm{G}$ proteins). J Biol Chem. 1988; 263; 6491-6494.

[59] Higashijima T, Burnier J, Ross EM. Regulation of Gi and Go by mastoparan, related amphiphilic peptides, and hydrophobic amines. Mechanism and structural determinants of activity. J Biol Chem. 1990; 265:14176-14186.

[60] Shpakov AO, Pertseva MN. Molecular invertebrates mechanisms for the effect of mastoparan on $G$ proteins in tissues of vertebrates and in vertebrates. Bull Exp Biol Med. 2006; 141:302-306. 
[61] Jones S, Howl J. Charge delocalization and the design of novel mastoparan analogues: enhanced cytotoxicity and secretory efficacy of [Lys5, Lys8, Aib10]MP. Regul Pept. 2004;15:121-128.

[62] Sugama J, Yu JZ, Rasenick MM, Nakahata N. Mastoparan inhibits betaadrenoceptorG(s) signaling by changing the localization of Galpha(s) in lipid rafts. Cell Signal 2007; 19:2247-2254.

[63] Shi J, Damjanoska KJ, Singh RK, Carrasco GA, Garcia F, Grippo AJ, Landry M, Sullivan NR, Battaglia G, Muma NA. Agonist induced-phosphorylation of Galpha11 protein reduces coupling to 5-HT2A receptors. J Pharmacol Exp Ther. 2007; 323:248-56.

[64] Shi J, Zemaitaitis B, Muma NA. Phosphorylation of Gq11 Protein Contributes to Agonist-Induced Desensitization of 5-HT2A Receptor Signaling. Mol Pharmacol. 2007; 71:303-313.

[65] Murthy KS, Makhlouf GM. Differential coupling of muscarinic $\mathrm{m} 2$ and $\mathrm{m} 3$ receptors to adenylyl cyclases V/VI in smooth muscle. Concurrent M2-mediated inhibition via Galphai3 and m3-mediated stimulation via Gbetagammaq. J Biol Chem. 1997; 272: 2131721324.

[66] Agulló L, Garcia-Dorado D, Escalona N, Ruiz-Meana M, Mirabet M, Inserte J, SolerSoler J. Membrane association of nitric oxide-sensitive guanylyl cyclase in cardiomyocytes. Cardiov Res. 2005; 68:65-74.

[67] Bidmon HJ, Mohlberg H, Habermann G, Buse E, Zilles K, Behrends S. Cerebellar localization of the NO-receptive soluble guanylyl cyclase subunits-alpha(2)/beta (1) in nonhuman primates. Cell Tissue Res. 2006; 326:707-714.

[68] Belligham M, Evans TJ. The $\alpha 2 \beta 2$ isoform of guanylyl cyclase mediates plasma membrane localized nitric oxide signaling. Cellular Signalling 2007; 19: 2183-2193.

[69] Papapetropoulos A, Simoes DC, Xanthou G, Roussos C, Gratziou C. Soluble guanylyl cyclase expression is reduced in allergic asthma. Am J Physiol Lung Cell Mol Physiol. 2006; 290: L179-L184.

[70] Hjoberg J, Shore S, Kobzik L, Okinaga S, Hallock A, Vallone J, Subramaniam V, De Sanctis GT, Elias JA, Drazen JM, Silverman ES. Expression of nitric oxide synthase-2 in the lungs decreases airway resistance and responsiveness. J Appl Physiol. 2004; 97: 249259.

[71] Placeres-Uray F, de Alfonzo RG, de Becemberg IL, Alfonzo MJ. Soluble guanylyl cyclase is reduced in airway smooth muscle cells from a murine model of allergic asthma. World Allergy Organiz J. 2010; 3: 271-276.

[72] [Placeres-Uray F, de Alfonzo RG, Alfonzo MJ, de Becemberg IL. Hypersensitivity of the $\mathrm{M}_{3} \mathrm{AChR} / \mathrm{Gq16}$ protein/NPR-GC-B coupling mechanism associated to muscarinic activation of airway smooth muscle cells in a rat asthma model. World Allergy Organization 2011 Annual Meeting. Boston. USA. (Abstract 81).

[73] Kolahian S, Gosens R. Cholinergic Regulation of Airway Inflammation and Remodelling. J Allergy (Cairo) 2012: 2012:681258. 